\title{
Penelusuran dan Konfirmasi Literatur
}

\author{
Ismail Suardi Wekke \\ *Pascasarjana Institut Agama Islam Negeri (IAIN) Sorong, Indonesia \\ **Necmettin Erbakan University, Turki \\ Email: iswekke@gmail.com
}

\begin{abstract}
ABSTRAK
Artikel ini mengidentifikasi bagaimana sebuah penelitian dilaksanakan. Dengan tidak serta merta menjadikan apa yang terlihat dan wujudnya tanda tanya. Namun, tanda tanya itu perlu ditahan sampai mendapatkan sebuah konfirmasi terkait denga napa yang sudah ada sebelumnya. Dinamakan dengan penelurusan dan konfirmasi literatur. Hanya saja, perlu syarat yang utama terkait dengan itu, yaitu validitas sebuah referensi.
\end{abstract}

Kata kunci: literatur, pondasi keilmuan, kebaruan

\section{Pendahuluan}

Ketika melihat sebuah fenomena, akan muncul pertanyaan. Hanya saja, pertanyaan-pertanyaan yang dikemukakan boleh jadi sudah ada jawabannya. Sehingga tidak perlu diteliti lagi. Jawaban sebelumnya, akan sama jikalau itu kembali dipublikasikan.

Penelitian saat ini merupakan kelanjutan dari apa yang sudah ada sebelumnya. Di tingkat pascasarjana, jangan lagi melakukan pengulangan. Apalagi kalau sebuah maklumat itu sudah masyhur dan dikenali di kalangan sarjana sebidang dalam ilmu yang ditekuni.

Untuk itu, capaian yang perlu dihasilkan dari mata kuliah ini adalah proposal tesis. Adapun penyusunan sebuah proposal tesis dikemukakan secara detail dalam sebuah file tersendiri (Wekke, 2019a). Secara komprehensif, penelitian akan tersaji secara lengkap dengan urutan dan prosedur yang terarah (Wekke, 2021).

\section{Penelusuran dan Konfirmasi Literatur}

Tahapan keempat dalam proses menemukan masalah penelitian adalah dengan konfirmasi literatur (Wekke, 2020). Ada alur yang perlu dilalui sehingga memungkinkan sebuah publikasi bisa terwujud (Farid \& Wekke, 2019).

Untuk itu, salah satu tahapan yang perlu dilakukan selanjutnya adalah dengan menelusuri literatur. Dimana mahasiswa sejak awal perlu mengenali pangkalan data kepustakaan yang memungkinkan untuk mendapatkan maklumat yang melimpah.

Setelah itu, literatur yang tersedia akan mengkonfirmasi pertanyaan yang muncul. Syarat pertama sebuah literatur yaitu valid (Wekke, 2019b). Ketika membaca sebuah kepustakaan, mahasiswa perlu membacanya secara kritis. Tidak memungkinkan untuk menerima informasi apa adanya (Wekke, 2019c).

Ketika informasi dikumpulkan, maka kemudian ditata sesuai dengan pengelompokan tema yang diinginkan. Selanjutnya melihat posisi dengan menjawab pertanyaan "apa yang belum diteliti?". Jawaban inilah yang kemudian disebut dengan state of the art (Rahayu, Syafril, Wekke, \& Erlinda, 2019). 
Antara satu literatur dengan literatur lainnya disintesis (Rahayu, Syafril, \& Wekke, 2019). Sehingga muncul kategori-kategori dan juga gambaran dalam bentuk pola terkait apa yang sudah diteliti sebelumnya.

Sehingga peneliti hanya melanjutkan dari apa yang sudah ada sebelum ini. Tidak lagi melakukan pengulangan. Literatur dalam sebuah publikasi ilmiah akan menjadi gambaran pondasi. Kemudian bagian hasil dan diskusi akan memberikan "tambahan" (Wekke, 2019c).

Pada bagian tambahan ini kemudian dinamakan dengan novelty. Sebuah hasil yang baru ditemukan yang akan memperkaya penelitian yang sudah ada.

\section{Penutup}

Sebuah publikasi baik yang tersaji dalam bentuk laporan ataupun artikel, menjadikan literatur sebagai bagian dalam komposisi keduanya. Ini yang menjadi kendala tersendiri bagi kalangan akademisi Indonesia dimana pada sebuah manuskrip selalu saja terdapat "kekeringan" dan "kekurangan" eksplorasi pada literatur.

Satu hal lagi, kekerapan terjadinya pengulangan sehingga menggangu perkembangan dan kelajuan ilmu pengetahuan. Diskursus keilmuan tidak pernah berkembang. Hanya berputar dan bahkan jangan sampai seperti poco-poco.

\section{Daftar Pustaka}

Cahyono, D., \& Wekke, I. S. (2018). Teknik penyusunan dan penulisan tesis. Yogyakarta: Deepublish.

Farid, M., \& Wekke, I. S. (2019). Proses Menulis Artikel Ilmiah: Dari Ide Hingga Publikasi. https://doi.org/10.31227/osf.io/yhpvm.

Rahayu, T., Syafril, S., \& Wekke, I. S. (2019). Menyintesis Literatur Dalam Penulisan Artikel. https://doi.org/10.31227/osf.io/fxnha.

Rahayu, T., Syafril, S., Wekke, I. S., \& Erlinda, R. (2019). Teknik Menulis Review Literatur Dalam Sebuah Artikel Ilmiah. https://doi.org/10.31227/osf.io/z6m2y.

Wekke, I. S. (2019a). Menulis Proposal Tesis. https://doi.org/10.31227/osf.io/dcr9v.

Wekke, I. S. (2019b). Validitas Referensi. https://doi.org/10.31227/osf.io/c4z5t.

Wekke, I. S. (2019c). Membaca Artikel Jurnal Secara Kritis. https://doi.org/10.31227/osf.io/4zagy.

Wekke, I. S. (2019c). Penelusuran Literatur Dalam Penulisan Artikel. https://doi.org/10.31227/osf.io/24tq6.

Wekke, I. S. (2020). Merumuskan Masalah Penelitian dengan Metode MAIL. https://doi.org/10.31219/osf.io/r5ack.

Wekke, I. S. (2021). Metode Penelitian Pendidikan Agama Islam Kepemimpinan Transformatif. Yogyakarta: Bintang Pustaka Madani. 